\title{
Insulin Sensitivity in Children Born Small for Gestational Age (SGA)
}

\author{
Caterina Geremia and Stefano Cianfarani \\ "Rina Balducci” Center of Pediatric Endocrinology, Department of Public Health and Cell Biology, Tor Vergata University, Via \\ Montpellier 1, 00133 Rome, Italy. Adress correspondence to: Stefano Cianfarani, e-mail: stefano.cianfarani@uniroma2.it.
}

\section{Abstract}

In the past decade, several epidemiological studies have shown a relationship between intrauterine growth retardation and insulin resistance, type 2 diabetes and cardiovascular disease in adulthood. Although the biological mechanisms underlying this association are still largely unknown, different explanatory hypotheses have been proposed. It seems likely that the various pathways may interact with each other, all contributing at different degrees to the development of the metabolic disturbances.

Keywords: SGA · gestational age · insulin sensitivity • type 2 diabetes $\cdot$ glucose intolerance $\cdot$ insulin resistance

Although most children who are born SGA experience catch-up growth and will achieve a height $>-2$ SD [6-11], intrauterine growth retardation is one of the major causes of short stature. Catch-up growth occurs in early postnatal life and in most children is completed by the age of 2 years [6, 7]. Approximately 10\% of SGA children will remain permanently $<-2$ SD for height [6, 7]. The mechanisms that allow catch-up growth in SGA children or, on the other hand, prevent them from achieving a normal height are still unknown $[12,13]$. We have suggested that catch-up growth in SGA children might be, at least in part, affected by intrauterine reprogramming of hypothalamic-pituitary-adrenal axis, children with increased cortisol secretion being at higher risk of growth failure. During the neonatal period cortisol might act by limiting IGFBP-3 proteolysis and, therefore, reducing IGF bioavailability [14].

During the last decade, after the first observations of Barker and co-workers in an adult population cohort, a number of long-term risks for SGA children were identified, including higher systolic blood pres- 
sure [15-17], increased cardiovascular mortality [18], elevated plasma cortisol [19], glucose intolerance, insulin resistance and type 2 diabetes [20-22], premature pubarche and ovarian hyperandrogenism [23, 24]. still unclear. Several models have been proposed and it is likely that each hypothesis might represent a different piece of the same puzzle (Figure 1).
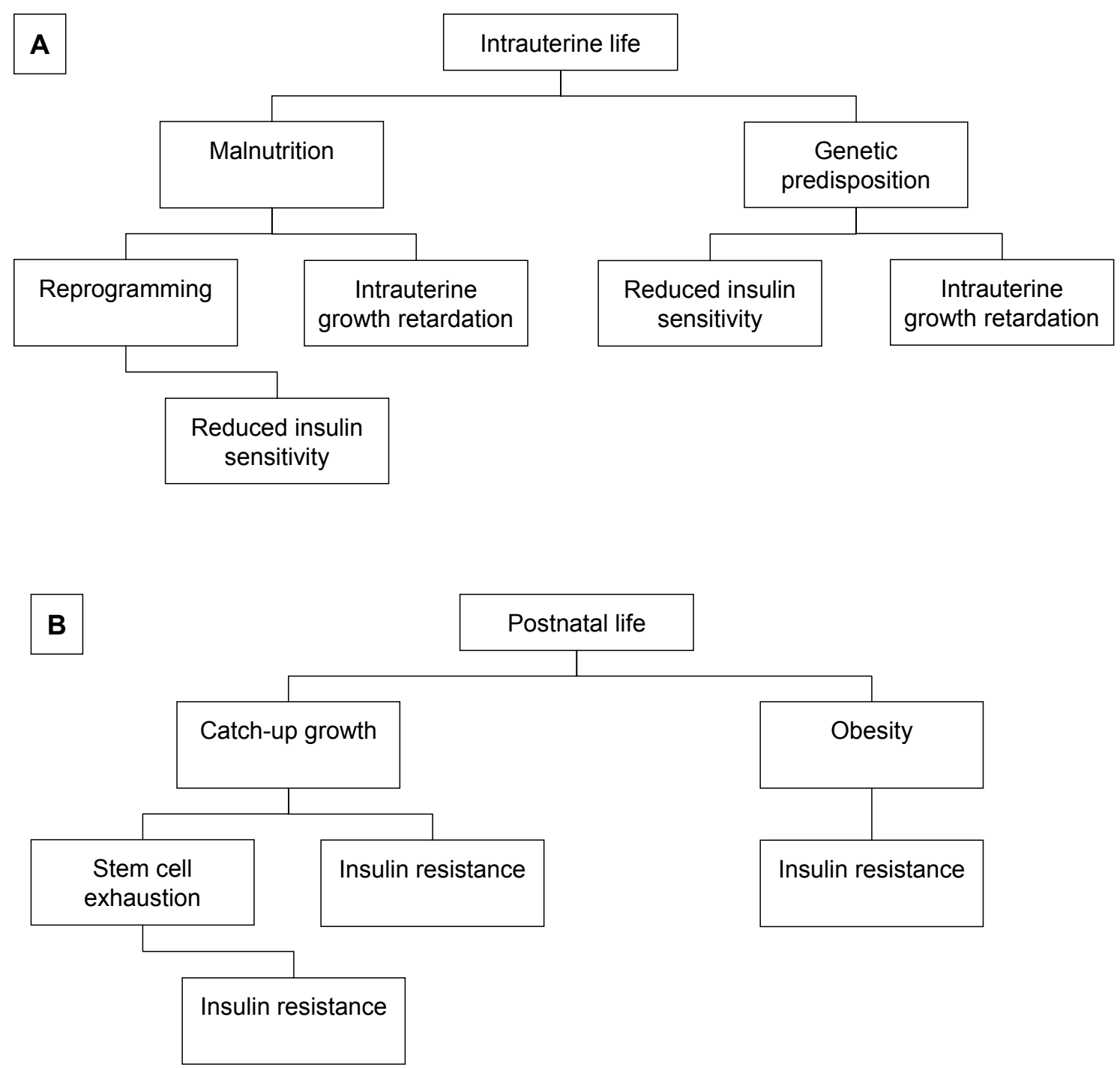

Figure 1. A summary of the mechanisms proposed to explain the association between intrauterine malnutrition and metabolic disturbances. During intrauterine life (A), fetal malnutrition leads to growth retardation and induces a reprogramming of both the endocrine system and metabolic pathways. When present, genetic predisposition may partly explain both intrauterine growth retardation and reduced insulin sensitivity. In postnatal life (B), rapid catch-up growth in weight and/or length might induce peripheral insulin resistance and lead to an early exhaustion of the tissue stem cell reservoir. Obesity represents the major additional risk factor for the development of insulin resistance.

\section{Underlying mechanisms}

Although knowledge of the mechanisms involved in the association between fetal growth impairment and metabolic risks might allow the development of new strategies to lower the prevalence of diabetes and coronary-artery disease, the pathophysiological link is

\section{The "thrifty phenotype" bypothesis}

The original "thrifty genotype" theory was proposed by Neel in 1962 [25] to explain the high prevalence of type 2 diabetes in Western populations. Neel hypothesized that genes favoring survival during famine would become detrimental when food supply be- 
come abundant, thus explaining the association between malnutrition and later development of metabolic complications.

In 1992 Hales and Barker proposed the "thrifty phenotype" hypothesis [26]. According to the thrifty phenotype model, the growing fetus exposed to nutritional deprivation adopts at least two strategies to aid survival [26]. First, it diverts nutrients to the brain to preserve brain growth at the expense of body growth and the development of other organs such as pancreas, liver, and muscle. Second, metabolic reprogramming occurs in a manner that is beneficial to survival under conditions of poor postnatal nutrition. However, if the organism is born into conditions of adequate or overnutrition, then this may conflict with the earlier reprogramming and insulin resistance, and, later on, type 2 diabetes may result [26]. The reprogramming process would occur during 'critical periods' of embryo-fetal life characterized by high cell proliferation rate in the developing tissues.

\section{The "fetal salvage" bypothesis}

This model rises from the observation that SGA children show a far greater insulin response than normal birthweight children. The "fetal salvage" model [27] suggests that the malnourished fetus develops peripheral insulin resistance, in an otherwise normal insulin secretion, which allows a redistribution of nutrients, such as glucose, in favor of essential organs. This then leads to a permanent reduction in skeletal muscle glucose transporter number or function. This reduced peripheral insulin sensitivity stimulates cells to produce larger amounts of insulin to achieve normal glycaemia and would lead to eventual cell exhaustion. This hypothesis is supported by studies in animal models showing reduced glucose transporter protein concentrations in skeletal muscles of intrauterine growth retarded fetuses and normal concentrations in the brain $[28,29]$.

\section{The "fetal insulin" bypothesis}

Hattersley and Tooke proposed that the association between low birthweight and adult insulin resistance is principally genetically mediated [30]. Genetically determined insulin resistance could result in low insulinmediated fetal growth in utero as well as insulin resistance in childhood and adulthood. Central to this hypothesis is the concept that insulin-mediated fetal growth will be affected by fetal genetic factors that regulate either fetal insulin secretion or the sensitivity of fetal tissues to the effects of insulin [30]. According to this model, polygenic genetic factors that increase insulin resistance, both in utero and in adult life, would produce two phenotypes: a small, thin baby and an adult with insulin resistance and increased risk of cardiovascular disease, particularly in the presence of obesity. Consistent with this hypothesis, Dunger et al. showed an association between common allelic variation (class I or class III) at the variable number of tandem repeat locus in the promoter region of the insulin gene and birth weight [31].

Results from Vassen and co-workers [32] support the hypothesis that genetic variation, by affecting fetal growth, could account for the association between low birth weight and susceptibility to diabetes and cardiovascular disease in later life. An association between a polymorphism in the promoter region of IGF-I gene and birth weight was found. Individuals who did not have the wild-type allele (192 bp) of the polimorphism had a $215 \mathrm{~g}$ lower birth weight than those homozygous for this allele. The same team previously showed that this genetic variation resulted in low circulating IGF-I concentrations, reduced height in adulthood, diminished insulin-secreting capacity, and a high risk of type 2 diabetes and myocardial infarction [33]. Taken together, their findings indicate that association between low birth weight, diabetes, and cardiovascular disease could be a result of genetic variation of the IGF-I gene, affecting both fetal growth and susceptibility to late-onset disease. A role of the polymorphism in the IGF-I gene in the development of fetal growth retardation has also been found by Arends and co-workers [34]. Finally, mutations of the IGF-I receptor have recently been described in two children with intrauterine growth retardation [35].

\section{The "catch-up growth" bypothesis}

SGA children show a rearrangement of the endocrine system at birth, having low concentrations of insulin, IGF-I, IGFBP-3, and high levels of the growth hormone, IGFBP-1 and IGFBP-2. Normalization of these parameters occurs early during the first trimester of life $[12,13]$. On the basis of this rapid adaptation to the extra-uterine environment, we have formulated the 'catch-up growth' hypothesis, suggesting that tissues chronically depleted of nutrients and, consequently, insulin and insulin-like growth factors (IGFs) during fetal life, in early postnatal life, being suddenly exposed to increased concentrations of the two hormones after normalization of nutrient supply, may counteract the additive insulin-like actions by developing insulin resis- 
tance [36]. According to this model, the first two years of life, when catch-up growth occurs in about $80 \%$ of IUGR children, represent the crucial time for the development of long-term consequences. Those SGA infants who show early and complete recovery from intrauterine growth retardation would be at higher risk for the occurrence of metabolic disturbances.

Several independent observations strongly support our hypothesis. Data from animals have shown that when fetal growth impairment is followed by catch-up growth postnatally, the lifespan is significantly shortened [37]. Moreover, the glucose induced insulin response in infants with catch-up growth is higher than that in children without significant catch-up growth [38]. Furthermore, an association between postnatal catch-up growth in height and/or weight and increased risk of developing type 2 diabetes in later life has been described [39-43]. Recently, Bazaes and co-workers [44] have also found a significant correlation between early postnatal growth rates and insulin sensitivity and secretion in childhood. The same research team in a prospective cohort of SGA and AGA infants, showed that both basal and first-phase insulin release are highly correlated with the extent of centile crossing in weight and length during the first year of life [45]. Finally, we have recently reported that concentrations of adiponectin, an adipocytokine with insulin-sensitizing and antiatherogenic properties, are reduced in SGA children, and are even lower in those with postnatal catchup growth [46].

\section{The "stem cell" bypothesis}

Another fascinating model stems from the finding that postnatal tissues contain stem cells that, though quiescent, retain their capacity to self-renew and regenerate tissues to fulfill organ demands. We have recently proposed that intrauterine malnutrition reduces tissue stem cell stores, eventually leading, in adulthood, to an early exhaustion of organ function, especially when demands are increased. According to this model, the 'critical periods' would correspond to the time windows of stem cell proliferation, early commitment and migration to the final destination in tissues [47]. Pancreas, endothelium, growth plate and brain might have a reduced stem cell reservoir and, hence, might not be able to face increased biological demands, ultimately exhausting their regeneration and repairing potential [47].

\section{Is glucose metabolism impaired in SGA chil- dren?}

Whilst several epidemiological surveys have confirmed the association between metabolic disturbances in adulthood and low birth size, few and conflicting data exist for childhood (Table 1). The potential impact of the early recognition of altered insulin sensitivity in clinical practice is high, because it might prompt the establishment of appropriate hormone-, diet-, or lifestyle-based strategies to prevent the long-term metabolic consequences of intrauterine growth retardation.

Yanjnik and colleagues performed a glucose tolerance test in 379 4-year-old low birthweight Indian children. 30 minutes after an oral glucose load, subjects with lower birth weights had higher plasma glucose and insulin levels, irrespective of their current size [48].

Law and colleagues carried out an abbreviated oral glucose tolerance test in 7-year-old children, finding that subjects who were thin at birth had higher plasma glucose concentration [49].

Hofman and colleagues [27] investigated insulin sensitivity in short prepubertal SGA children compared with short prepubertal children born with a birth weight appropriate for gestational age. They found that the SGA group was less insulin-sensitive than controls, although there were no differences in the plasma glucose.

Veening et al. found no significant difference in glucose tolerance and beta-cell function between the SGA and AGA groups. However, the hyperinsulinemic clamp showed a reduced insulin sensitivity in SGA children, especially in SGA children with catchup growth and a high BMI [39]. The same research group studied beta-cell capacity and insulin sensitivity in 28 prepubertal SGA children and in 22 prepubertal AGA children. The SGA children showed decreased insulin sensitivity rather than decreased beta-cell capacity [50].

Whincup performed a school-based survey of 10to 11 -year-old British children. 590 children were studied in fasting conditions while 547 were investigated 30 minutes after a standard oral glucose load. Neither fasting nor post-load glucose levels showed any relationship with birth weight or ponderal index at birth. After adjustment for childhood height and ponderal index, both fasting and post-load insulin levels decreased with increasing birth weight [51]. The authors concluded that low birth weight is not related to glu- 
cose intolerance at 10-11 years, but may be related to the early development of insulin resistance [51].

After an oral glucose challenge, Potau and colleagues showed the presence of high insulin levels in an early marker of insulin resistance in adulthood [52].
51 children and 49 adolescents born SGA compared to normal subjects born AGA and proposed that this elevated insulin concentration might be considered as 1 year of age. SGA subjects were subdivided into children with weight or length catch-up growth.

Table 1. Published studies carried out in children

\begin{tabular}{|c|c|c|c|c|}
\hline Reference & No. of patients & Age & Test & Results \\
\hline Yanjnik et al. (1995) & 379 & $4 y$ & $\mathrm{OGTT}^{\mathrm{a}}$ & Higher insulin levels \\
\hline Law et al. (1995) & 250 & $7 y$ & SOGTT & Higher glucose concentrations \\
\hline Hofman et al. (1997) & 15 & $6-11 y$ & $\mathrm{FSIGT}^{\mathrm{C}}$ & $\begin{array}{l}\text { Higher insulin levels and lower } \\
\text { insulin sensitivity }\end{array}$ \\
\hline Whincup et al. (1997) & 1137 & $10-11 y$ & $\begin{array}{l}\text { Group 1. Fasting glucose and } \\
\text { insulin concentration (590) } \\
\text { Group 2. Glucose and insulin 30' } \\
\text { after glucose load (547) }\end{array}$ & $\begin{array}{l}\text { Fasting and post load insulin } \\
\text { levels increased with decreasing } \\
\text { birth weight }\end{array}$ \\
\hline Potau et al. (2001) & 100 & $\begin{array}{l}9 \text { y }(51) \\
17 \text { y }(49)\end{array}$ & $\mathrm{OGTT}^{\mathrm{a}}$ & Higher insulin levels \\
\hline Woods et al. (2002) & 16 & $2.3-8 y$ & $\begin{array}{l}\text { Fasting glucose and insulin } \\
\text { concentration (HOMA) }\end{array}$ & $\begin{array}{l}\text { Reduced insulin sensitivity and } \\
\text { increased beta cell function }\end{array}$ \\
\hline Soto et al. (2002) & 85 & $1 \mathrm{y}$ & SIVGTT & $\begin{array}{l}\text { Fasting insulin higher in SGA } \\
\text { infants with weight catch-up } \\
\text { growth. Length increment corre- } \\
\text { lated with post-load insulin }\end{array}$ \\
\hline Gray et al. (2002) & 100 & $16 d$ & $\begin{array}{c}\text { Glucose levels after a standard- } \\
\text { ized milk feed }\end{array}$ & Higher insulin levels \\
\hline Veening et al. (2002) & 29 & $8-10 y$ & $\begin{array}{c}\text { OGTT }^{\mathrm{a}} \\
\text { Hyperinsulinemic-euglycemic } \\
\text { clamp }\end{array}$ & $\begin{array}{l}\text { No difference in glucose toler- } \\
\text { ance and } \beta \text { cell function. } \\
\text { Reduced insulin sensitivity }\end{array}$ \\
\hline Veening et al. (2003) & 28 & $1-9 y$ & $\begin{array}{l}\text { Hyperinsulinemic-euglycemic } \\
\text { clamp plus Arginine }\end{array}$ & $\begin{array}{l}\text { Reduced insulin sensitivity. } \beta \text { - } \\
\text { cell function preserved }\end{array}$ \\
\hline Cianfarani et al. (2003) & 82 & $5.1-12.1 y$ & $\begin{array}{l}\text { Fasting glucose and insulin } \\
\text { concentration (HOMA) }^{d}\end{array}$ & $\begin{array}{l}\text { No altered insulin sensitivity, } \\
\text { reduction of glucose levels }\end{array}$ \\
\hline
\end{tabular}

${ }^{a}$ Oral glucose tolerance test. ${ }^{b}$ Short oral glucose tolerance test. ${ }^{c}$ Frequently sampled IV glucose tolerance test. ${ }^{d}$ Homeostasis model assessment. ${ }^{\text {e }}$ Short IV glucose tolerance test.

Woods et al. demonstrated that short SGA children have reduced insulin sensitivity and increased beta cell function as if higher insulin concentrations were needed to maintain a normal glucidic homeostasis. These two variables were significantly related to overnight GH secretion. An elevated pattern of GH secretion, similar to that observed during fasting and malnutrition, was observed and the authors postulated that resistance to the somatotropic actions of $\mathrm{GH}$ and IGF-I in short SGA children may contribute directly to reduced insulin sensitivity [53].

Soto et al. investigated whether SGA infants have decreased insulin sensitivity compared to AGA ones at Fasting insulin was significantly higher in SGA chil- dren that had weight catch-up growth, compared with those who did not catch-up and AGA infants. On the other hand, length increment was the principal determinant of post-load insulin secretion. Therefore, fasting insulin sensitivity was related to weight catch-up growth and actual BMI, whereas insulin secretion was directly related to length catch-up growth [45].

Gray and colleagues studied 100 premature and/or small for gestational age infants (age range: 1-65 days). Fasting and postprandial glucose and insulin levels were measured. Following a standardized milk feed, birth weight influenced the glucose concentration, while gestational age did not. SGA neonates had higher 60-minute insulin levels than AGA neonates 
despite similar glucose levels. Postnatal growth velocity correlated with birth weight and insulin resistance independently of each other. The authors suggested that glucose tolerance of the neonate is determined by weight attained at birth irrespective of gestational age and that maternal blood pressure may influence insulin sensitivity of the newborn. Furthermore, their findings indicate that catch-up growth in neonates is determined by birth weight and insulin sensitivity [54].

Although several reports suggest reduced insulin sensitivity in SGA children, to date very few strict case-control studies have been carried out. We have recently investigated the endocrine status in SGA children, compared with children born appropriate for gestational age (AGA), strictly matched for age, sex, pubertal status, body mass index (BMI), and height [55]. SGA subjects did not have differences in the indices of insulin sensitivity, but showed significantly lower baseline glucose levels. This finding is consistent with recent studies in animal models using a lowprotein diet during pregnancy to produce growth restriction of the offspring [56]. In young adult life, lowprotein offspring have an improved glucose tolerance, compared with controls [57, 58]. This is associated with increased muscle and adipocytes insulin receptors and augmented insulin-stimulated glucose uptake into skeletal muscle [59] and adipocytes [60]. Later on, however, offspring undergo an age-dependent loss of glucose tolerance, such that by 15 months of age, lowprotein offspring have a significantly worse glucose tolerance, compared with controls [58]. We speculated that, in human, an early phase of increased insulin sensitivity during childhood might precede the onset of insulin resistance in young adult SGA subjects.

\section{Conclusions}

There is increasing epidemiological evidence suggesting that certain metabolic disorders in adults such as insulin resistance and type 2 diabetes might originate from in utero malnutrition. Although many hypotheses have been proposed, the molecular mechanisms underlying this epidemiological association are still unknown. Much less clear is the impact of low birth weight on glucose homeostasis in childhood. Most published reports indicate only subtle abnormalities of insulin secretion and/or insulin sensitivity with no alterations of glucose metabolism in SGA children. A meta-analysis might be appropriate to integrate the results of several independent studies and critically review all the available data for childhood. At the same time, longitudinal case-control studies on large cohorts of children from birth to adolescence are needed to quantify the metabolic risk, identify the critical time windows, and determine the effects of other risk factors, such as obesity or genetic predisposition (Figure 2).

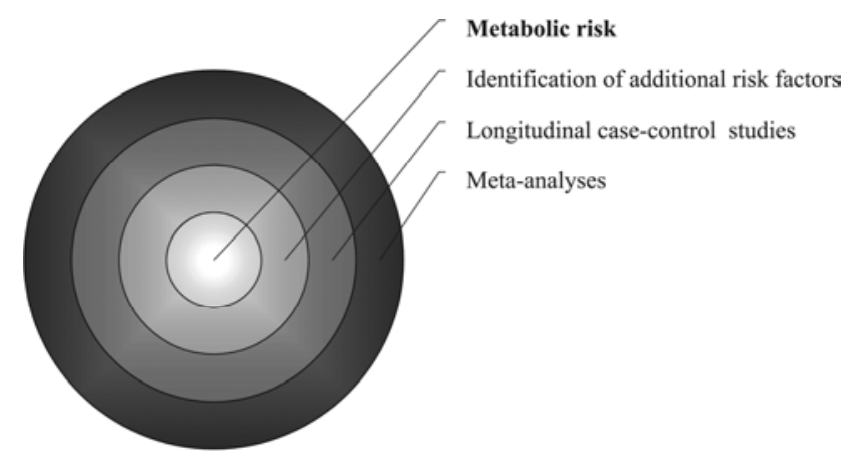

Figure 2. Strategies to ascertain and quantify the metabolic risk in SGA children.

Acknowledgments: The work was supported in part by MIUR, grant COFIN 40\%-2003064547.

\section{$\square$ References}

1. Lee AP, Chernausek SD, Hokken-Koelega AC, Czernichow P. International small for gestational age advisory board consensus development conference statement: management of short children born small for gestational age, April 24-October 1 2001. Pediatrics 2003. 111:1253-1261.

2. Markestad T, Vik T, Ahlsten G, Gebre-Medhin M, Skjaerven R, Jacobsen G, Hoffman HJ, Bakketeig LS. Small-for-gestational-age (SGA) infants born at term: growth and development during the first year of life. Acta Obstet Gynecol Scand Suppl 1997.165:93-101.

3. Bernstein PS, Divon MY. Etiologies of fetal growth restriction. Clin Obstet Gynecol 1997. 40:723-729.
4. Pollack RN, Divon MY. Intrauterine growth retardation: definition, classification and etiology. Clin Obstet Gynecol 1992. 35:99-107.

5. Wollmann HA. Intrauterine growth restriction: definition and etiology. Horm Res 1998. 49(Suppl 2):1-6.

6. Fitzhardinge $\mathbf{P M}$, Stevan EM. The small for date infant later growth patterns. Pediatrics 1972. 49:671-681.

7. Karlberg J, Albertsson-Wickland K. Growth in full-term small-for-gestational-age infants: from birth to final height. $P e$ diatr Res 1995. 38:733-739.

8. Ong KI, Ahmed MI, Emmet PM, Preece MA. For the Avon Longitudinal Study of Pregnancy and Childhood Study Team. Association between postnatal catch-up growth and obesity in childhood: prospective cohort study. BMJ 2000. 
320:967-971.

9. Albertsson-Wickland K, Karlberg JPE. Postnatal growth of children born small for gestational age. Acta Ped Suppl 1997. 423:193-195.

10. Karlberg JPE, Albertsson-Wickland K, Kwan EYW, Lam BCC. The timing of early postnatal catch-up growth in normal, full term infants born small for gestational age. Horm Res 1997. 48(Suppl 1):17-24.

11. Leger J, Levy-Marchal C, Bloch J. Reduced final height and indication for insulin resistance in 20-year-olds born small for gestational age: regional cohort study. BMJ 1997. 315: 341-347.

12. Leger J, Noel M, Limal KM, Czernichow P. Growth factors and intrauterine growth retardation. Serum growth hormone, insulin-like growth factor I, and IGF-binding protein-3, levels in children with intrauterine growth retardation compared with normal control subjects: prospective study from birth to two years of age. Pediatr Res 1996. 40:101-107.

13. Cianfarani S, Germani D, Rossi P, Rossi L, Germani A, Ossicini C, Zuppa A, Argirò G, Holly JMP, Branca F. Intrauterine growth retardation: evidence for the activation of the insulin-like growth factor (IGF)-related growth-promoting machinery and the presence of a cation-independent IGF binding protein-3 proteolytic activity by two months of life. Pediatr Res 1998. 44:374-380.

14. Cianfarani S, Geremia C, Scott CD, Germani D. Growth, IGF system, and cortisol in children with intrauterine growth retardation: is catch-up growth affected by reprogramming of the hypothalamic-pituitary-adrenal axis? Pediatr Res 2002. 51:9499.

15. Barker DJ, Osmond C, Golding J, Kuh D, Wadsworth ME. Growth in utero, blood pressure in childhood and adult life, and mortality from cardiovascular disease. BMJ 1989. 298(6673):564-567.

16. Barker DJ. The fetal origins of adult hypertension. J Hypertension 1992. 10:S39-S44.

17. Barker DJ. Fetal origins of coronary disease. BMJ 1995. 311:171-174.

18. Barker DJ, Winter PD, Osmond C, Margetts B, Simmonds SJ. Weight in infancy and death from ischaemic heart disease. Lancet 1989. 2:577-580.

19. Phillips DI, Barker DJ, Fall CH, Seckl JR, Whorwood CB, Wood PJ, Walker BR. Elevated plasma cortisol concentrations: a link between low birth weight and the insulin resistance syndrome? J Clin Endocrinol Metab 1998. 83:757-760.

20. Hales CN, Barker DJ, Clark PM, Cox LJ, Fall C, Osmond C, Winter PD. Fetal and infant growth and impaired glucose tolerance at age 64. BMJ 1991. 303:1019-1022.

21. Valdez R, Athens MA, Thompson GH, Bradshaw BS, Stern MP. Birth-weight and adult health outcomes in a biethnic population in USA. Diabetologia 1994. 37:624-631.

22. Barker DJ, Hales CN, Fall CH, Osmond C, Phipps K, Clark PM. Type 2 (non-insulin-dependent) diabetes mellitus, hypertension and hyperlipidaemia (syndrome $\mathrm{X}$ ): relation to reduced fetal growth. Diabetologia 1993. 36(1):62-67.

23. Ibanez L, Potau N, Francois I, de Zegher F. Precocious pubarche, hyperinsulinism, and ovarian hyperandrogenism in girls: relation to reduced fetal growth. J Clin Endocrinol Metab 1998. 83:3558-3562.

24. Ibanez L, Potau N, Marcos MV, de Zegher F. Exaggerated adrenarche and hyperinsulinism in adolescent girls born small for gestational age. J Clin Endocrinol Metab 1999. 84:4739-4741.

25. Neel JV. Diabetes mellitus. A "thrifty" genotype rendered detrimental by "progress". Am J Hum Genet 1962.14:353-362.
26. Hales CN, Barker DJ. Type 2 (non-insulin-dependent) diabetes mellitus: the thrifty phenotype hypothesis. Diabetologia 1992. 35:595-601.

27. Hofman PL, Cutfield WS, Robinson EM, Bergman RN, Menon RK, Sperling MA, Gluckman PD. Insulin resistance in short children with intrauterine growth retardation. J Clin Endocrinol Metab 1997. 82:402-406.

28. Simmons RA, Gounis AS, Bangalore SA, Ogata ES. Intrauterine growth retardation: fetal glucose transport is diminished in lung but spared in brain. Pediatr Res 1985. 31:59-63.

29. Simmons RA, Flozak AS, Ogata ES. The effect of insulin, and insulin-like growth factor I on glucose transport in normal and small for gestational age fetal rats. Endocrinology 1993. 133:1361-1368

30. Hattersley AT, Tooke JE. The fetal insulin hypothesis: an alternative explanation of the association of low birthweight with diabetes and vascular disease. Lancet 1999. 353:1789-1792.

31. Dunger DB, Ong KK, Huxtable SJ, Sherriff A, Woods KA, Ahmed ML, Golding J, Pembrey ME, Ring S, Bennett ST, et al. Association of the INS VNTR with size at birth. ALSPAC study team. Avon longitudinal study of pregnancy and childhood. Nat Genet 1998.19:98-100.

32. Vaessen N, Janssen JA, Heutink P, Hofman A, Lamberts SWJ, Oostra BA, Pols HA, van Duijn CM. Association between genetic variation in the gene for insulin-like growth factor-I and low birthweight. Lancet 2002. 23;359(9311):10361037.

33. Vaessen N, Heutink P, Janssen JA, Witteman JCM, Tetsres L, Hofman A, Lamberts SWJ, Oostra BA, Pols HAP, van Duijn CM. A polymorphism in the gene for IGF-I. Functional properties and risk for type 2 diabetes and myocardial infarction. Diabetes 2001. 50:637-642.

34. Arends N, Johnston L, Hokken-Kolega A, Van Duijn C, De Ridder M, Savage M, Clark A. Polymorphism in the IGF-I gene: clinical relevance for short children born small for gestational age (SGA). J Clin Endocrinol Metab 2003. 87:27202724 .

35. Abuzzahab MJ, Schneider A, Goddard A, Grigorescu F, Lautier C, Keller E, Kiess W, Klammt J, Kratzsch J, Osgood D, et al. IGF-I receptor mutations resulting in intraueterine and postnatal growth retardation. $N$ Engl J Med 2003. 349:2211-2222.

36. Cianfarani S, Germani D, Branca F. Low birth weight and adult insulin resistance: "The catch-up growth" hypothesis. Arch Dis Child 1999. 81:F71-F73.

37. Hales CN, Desai M, Ozanne SE, Crowther NJ. Fishing in the stream of diabetes: from measuring insulin to the control of fetal organogenesis. Biochem Soc Trans 1996. 24:341-350.

38. Colle E, Schiff D, Andrew G, Bauer CB, Fitzhardinge P. Insulin responses during catch-up growth of infants who were small for gestational age. Pediatrics 1976. 57:363-371.

39. Veening MA, Van Weissenbruch MM, Delemarre-Van De Waal HA. Glucose tolerance, insulin sensitivity, and insulin secretion in children born small for gestational age. J Clin Endocrinol Metab 2002. 87:4657-4661.

40. Eriksson JG, Forsen T, Tuomilehto J, Winter PD, Osmond C, Barker DJ. Catch-up growth in childhood and death from coronary heart disease: longitudinal study. BMJ 1999. 318:427-431.

41. Bavdekar A, Yajnik CS, Fall CHD, Bapat S, Pandit AN, Deeshpande V, Bhave S, Kellingray SD, Joglekar C. Insulin resistance syndrome in 8 -year-old Indian children. Diabetes 1999. 48:2422-2429. 
42. Ong KKL, Ahmed ML, Emmett PM, Preece MA, Dunger DB. Association between postnatal catch-up growth and obesity in childhood: prospective cohort study. BMJ 2000. 320:967-971.

43. Singhai A, Fewtrell M, Cole TJ, Lucas A. Low nutrient intake and early growth for later insulin resistance in adolescents born preterm. Lancet 2003. 361:1089-1097.

44. Bazaes RA, Alegria AL, Pittaluga E, Avila A, Iniguez G, Mericq V. Determinants of insulin sensitivity and secretion in very-low-birth-weight children. J Clin Endocrinol Metab 2004. 89:1267-1272.

45. Soto N, Bazaes RA, Pena W, Salazar T, Avila A, Iniguez G, Ong KK, Dunger DB, Mericq V. Insulin sensitivity and secretion are related to catch-up growth in small-forgestational-age infants at age one year: results from a prospective cohort. J Clin Endocrinol Metab 2003. 88:3645-3650.

46. Cianfarani S, Martinez C, Maiorana A, Spadoni GL, Scire G, Boemi G. Adiponectin levels are reduced in children born small for gestational age (SGA) and are inversely related to postnatal catch-up growth. J Clin Endocrinol Metab 2004. 89:1346-1351.

47. Cianfarani S. Fetal origins of adult diseases: just a matter of stem cell number? Med Hypoth 2003. 61:401-404.

48. Yajnik CS, Fall CH, Vaidya U, Pandit AN, Bavdekar A, Bhat DS, Osmond C, Hales CN, Barker DJ. Fetal growth and glucose and insulin metabolism in four-year-old Indian children. Diabet Med 1995.12(4):330-336.

49. Law CM, Gordon GS, Shiell AW, Barker DJ, Hales CN. Thinness at birth and glucose tolerance in seven-year-old children. Diabet Med 1995.12(1):24-29.

50. Veening MA, van Weissenbruch MM, Heine RJ, Delemarre-van de Waal HA. Beta-cell capacity and insulin sensitivity in prepubertal children born small for gestational age: influence of body size during childhood. Diabetes 2003. 52(7):1756-1760.

51. Whincup PH, Cook DG, Adshead F, Taylor SJ, Walker M, Papacosta O, Alberti KG. Childhood size is more strongly re- lated than size at birth to glucose and insulin levels in 10-11year-old children. Diabetologia 1997. 40(3):319-326.

52. Potau N, Gussinye M, Sanchez Ufarte C, Rique S, Vicens-Calvet E, Carrascosa A. Hyperinsulinemia in preand post-pubertal children born small for gestational age. Horm Res 2001. 56(5-6):146-150.

53. Woods KA, Van Helvoirt M, Ong KKL, Mohon A, Levy J, De Zegher F, Dunger DB. The somatotropic axis in short children born small for gestational age: relation to insulin resistance. Pediatr Res 2002. 51:76-80.

54. Gray IP, Cooper PA, Cory BJ, Toman M, Crowther NJ. The intrauterine environment is a strong determinant of glucose tolerance during the neonatal period, even in prematurity. J Clin Endocrinol Metab 2002. 87(9):4252-4256.

55. Cianfarani S, Maiorana A, Geremia C, Scire G, Spadoni GL, Germani D. Blood glucose concentrations are reduced in children born small for gestational age (SGA), and thyroidstimulating hormone levels are increased in SGA with blunted postnatal catch-up growth. J Clin Endocrinol Metab 2003. 88:2699-2705.

56. Desai M, Crowther NJ, Lucas A, Hales CN. Organselective growth in the offspring of protein-restricted mothers. Br J Nutr 1996. 76(4):591-603.

57. Langley SC, Browne RF, Jiacson AA. Altered glucose tolerance in rats exposed to maternal low protein diets in utero. Comp Biochem Phisiol 1994. 109:223-229.

58. Hales CN, Desai M, Ozanne SE, Crowther NJ. Fishing in the stream of diabetes: from measuring insulin to the control of fetal organogenesis. Biochem Soc Trans 1996. 24(2):341-350.

59. Ozanne SE, Wang CL, Coleman N, Smith GD. Altered muscle insulin sensitivity in the male offspring of proteinmalnourished rats. Am I Physiol 1996. 271(6 Pt 1):E1128-1134.

60. Ozanne SE, Nave BT, Wang CL, Shepherd PR, Prins J, Smith GD. Poor fetal nutrition causes long-term changes in expression of insulin signaling components in adipocytes. Am J Physiol 1997. 273(1 Pt 1):E46-51. 